\title{
Conjunctivodacryocystorhinostomy using Métaireau Tube with Endoscopy Assistance
}

\section{Gamze Ozturk Karabulut}

Department of Ophthalmic Plastic and Reconstructive Surgery, University of Health Sciences, Beyoglu Eye Training and Research Hospital, Istanbul, Turkey

\begin{abstract}
Objectives: The purpose of this study was to analyze the surgical outcome of conjunctivodacryocystorhinostomy (CDCR) operations with permanent silicone tube implantation (Métaireau tube) with the aid of nasal endoscopy and to obtain subjective measure of patient satisfaction.

Methods: Charts of I 3 eyes of 13 patients (five males and eight females) with proximal canalicular obstruction who had undergone CDCR with permanent silicone tube insertion were reviewed retrospectively. Diagnosis of the upper lacrimal system obstruction was confirmed by lacrimal system irrigation. During operation, the length of the tube was adjusted with the aid of nasal endoscopy using the endoscopic scissors to prevent contact of the distal end of the tube to the nasal septum in the nasal cavity. The patients were asked to subjectively rate their epiphora according to Munk Epiphora Grading System before surgery and at $\mathrm{I}^{\text {st }}, 3^{\text {rd }}$, and $6^{\text {th }}$ months, and I year following surgery.

Results: Improvement of epiphora was statistically significant at all visits when compared with values before injection $(p<0.00 \mathrm{I})$. Tube dislocation was seen in 4 patients $(30.7 \%)$, proximal obstruction due to conjunctival granuloma formation was seen in 3 patients (23\%). Two patients who had tube dislocation intranasally were revised for 2 times with endoscopy and proximal ends of tubes were resutured. Repositioning of the tube by pulling out from caruncle area with fine forceps was performed only once in two patients.

Conclusion: CDCR with permanent silicone tube insertion and adjustment of the length of the tube with assistance of endoscopy provides easier and efficient approach in patients with proximal lacrimal system obstruction.

Keywords: Complications of conjunctivodacryocystorhinostomy, conjunctivodacryocystorhinostomy, Jones tube, Métaireau tube.
\end{abstract}

\section{Introduction}

Conjunctivodacryocystorhinostomy (CDCR) was first described by Von Hoffman in 1904, Kraupa and Goar described the technique in the following years also $(I, 2)$. Stallard (3) described a procedure in which they opened the fundus of lacrimal sac and sutured to the conjunctiva without a permanent stent. To overcome lacrimal system obstruction, several other techniques such as the use of buccal mucosa, vein grafts, and hydrophilic tube prepared from sclera, silicone rubber tubes were also described $(2,4,5)$. CDCR and a Pyrex tube (Weiss Scientific Glass Blowing Company, Portland, OR, U.S.A) implantation were first described by Jones in 1965 (6). Since that time, CDCR with permanent tube implantation for the treatment of epiphora due to non-reconstructable upper lacrimal system obstruction has become the conventional approach (7).

Lacrimal canalicular obstruction can be caused by congenital agenesis, surgical removal of canaliculus or punctum, herpetic infection, trauma, tumors, inflammation, lichen

Address for correspondence: Gamze Ozturk Karabulut, MD. Beyoglu Goz Egitim ve Arastirma Hastanesi, Saglik Bilimleri Universitesi, Oftalmik Plastik ve Rekonstruktif Cerrahi Klinigi, Istanbul, Turkey

Phone: +90 5326061303 E-mail: gokarabulut@gmail.com

Submitted Date: October 21, 2018 Accepted Date: December 18, 2018 Available Online Date: December 27, 2018

${ }^{\odot}$ Copyright 2018 by Beyoglu Eye Training and Research Hospital - Available online at www.beyoglueye.com 
planus, Steven-Johnson's syndrome, systemic chemotherapy (usually docetaxel treatment), radiation therapy, and canalicular dysfunction in facial nerve palsy or as a complication of unsuccessful DCR $(2,7,8)$. However, the cause of obstruction is mostly unknown. In this article, our aim was to analyze the surgical outcome of CDCR operation with permanent silicone tube implantation coated with polyvinylpyrrolidone (PVP) (Métaireau tube, France Chirurgie Instrumentation ( $\mathrm{FCl}$ ) S.A.S. - France Chirurgie Instrumentation 20-22 rue Louis Armand 75015 PARIS - France) with aid of nasal endoscopy and to obtain subjective measure of patient satisfaction.

\section{Methods}

A total of 13 eyes of 13 patients who had epiphora due to upper lacrimal system obstruction which was described as $<8 \mathrm{~mm}$ of healthy proximal canaliculus and undergone CDCR with Métaireau tube insertion between 2014 and 2017 were enrolled in this study and charts of patients were reviewed retrospectively. An informed consent was obtained from all patients in accordance with the Helsinki Declaration and the study was approved by local Ethics Committee. All patients underwent clinical examination including visual acuity, slit lamp microscopy, eyelid position, and lacrimal syringing. Consultation from otorhinolaryngologist was obtained for every patient to exclude nasal cavity problem. All patients underwent routine ophthalmological examination. Diagnosis of upper lacrimal system obstruction was based on lacrimal system irrigation to confirm complete obstruction or insufficient tissue to perform canalicular reconstruction. During lacrimal system irrigation, the place of canalicular obstruction and measurement of healthy canaliculus from punctum in $\mathrm{mm}$ were noted. The patients were asked to subjectively rate their epiphora according to Munk Epiphora Grading System (9) (Table I) before surgery and on the $10^{\text {th }}$ day, I $^{\text {st }}, 3^{\text {rd }}$, and $6^{\text {th }}$ months.

CDCR with Métaireau tube insertion was performed by using classical Dupuy-Dutemps-Bourguet technique. Skin was incised beginning from the level of inferior margin of medial canthal ligament and incision was made parallel to the orbital rim approximately $10-15 \mathrm{~mm}$ long. After blunt dissection and cleavage of periosteum, nasolacrimal sac was

Table I. Epiphora grading scale according to Munk (10)

\section{No epiphora}

Occasional epiphora requiring drying or dabbing less than twice daily (<2 times)

Epiphora requiring dabbing 2-4 times daily (2-4 times)

Epiphora requiring dabbing 5-10 times daily (5-10 times)

Epiphora requiring dabbing $>10$ times daily or constant tearing $(>10$ times) reflected laterally. Anterior lacrimal crest and wall of lacrimal fossa were then removed. Attention was paid to create the bony ostium most inferiorly to enable easy drainage of tears down the tube. "H"-shaped incisions were made in the medial wall of lacrimal sac and nasal mucosa followed by anastomosis of posterior flaps where possible. After excision of caruncle, a bypass was created from conjunctiva to nasal cavity. The silicone tube was inserted into the newly created ostium with guidance of lacrimal probe and the length of the tube was adjusted with the aid of nasal endoscopy using the endoscopic scissors to prevent contact of the distal end of the tube to the nasal septum in the nasal cavity. Silicone tubes were fixated to the conjunctiva by passing $6 / 0$ polyglactin suture through the flange. After anastomosis of anterior lacrimal sac flap and nasal mucosal flap, subcutaneous tissue, and skin were closed.

Patients were prescribed systemic and topical antibiotics, nasal decongestant sprays, and artificial teardrops for I week and were given instructions such as regular sniffing, but not blowing nose without a finger held over proximal end of tube, wiping the tube with a cotton swab to remove mucus, and forceful aspiration of water or saline to maintain patency. All patients were asked to return if a problem arouses, otherwise controlled at $10^{\text {th }}$ day, 1 month, 3 months, 6 months, and I year.

All statistical analyses were performed with SPSS for Windows Ver. 22 (IBM Corp., Armonk, NY, USA). P<0.05 was considered to be statistically significant.

\section{Results}

Of the 13 patients, five were male and eight were female with a mean age of $47.38 \pm 10.6$ years (29-69 years). The mean length of follow-up was $23.9 \pm 8.3$ months, ranging from 12 to 40 months. The most common etiology was canalicular obstruction as a complication of unsuccessful DCR (6 eyes, 46.1\%) where four of them had transcanalicular laser-assisted DCR, which was followed by trauma ( 3 eyes, $23 \%$ ), conjunctivitis (2 eyes, 15.3\%). In two patients, the etiology was unknown (15.3\%) (Table 2).

The mean Munk score was 4 in all patients before surgery where improvement of epiphora was statistically significant at $1^{\text {st }}, 3^{\text {rd }}$, and $6^{\text {th }}$ months, and I year $(1.62,1.25,1.4$, and I.82, respectively) $(P<0.000$ I for all of the controls, Chisquare test).

Tube dislocation was seen in 4 patients (30.7\%) and proximal obstruction due to conjunctival granuloma formation was seen in 3 patients (23\%). Tube dislocations were seen in the first 3 months. However, granuloma formation was seen at the $6^{\text {th }}$ month in one patient, after I year in two patients. All patients who had post-operative complications were revised for their problem. Two patients who had tube disloca- 
Table 2. Patient characteristics, etiology, and surgical results

\begin{tabular}{|c|c|c|c|c|c|c|c|}
\hline $\begin{array}{l}\text { Patient } \\
\text { number }\end{array}$ & Sex & Age & Etiology & Follow-up (mo) & Complications & $\begin{array}{c}\text { Pre-operative } \\
\text { Munk }\end{array}$ & $\begin{array}{c}\text { Post-operative } \\
\text { Munk (last } \\
\text { follow-up) }\end{array}$ \\
\hline I & $\mathrm{F}$ & 69 & Unknown & 18 & Tube dislocation & 4 & I \\
\hline 2 & $\mathrm{~F}$ & 43 & Transcanalicular laser DCR & 32 & & 4 & I \\
\hline 3 & $\mathrm{~F}$ & 46 & Transcanalicular laser DCR & 24 & Granuloma & 4 & 2 \\
\hline 4 & $\mathrm{~F}$ & 47 & Conjunctivitis & 21 & Tube dislocation & 4 & I \\
\hline 5 & $\mathrm{~F}$ & 45 & Unknown & 13 & & 4 & 2 \\
\hline 6 & $\mathrm{~F}$ & 62 & Unsuccessful DCR & 36 & & 4 & 2 \\
\hline 7 & $\mathrm{~F}$ & 55 & Conjunctivitis & 12 & Tube dislocation & 4 & 3 \\
\hline 8 & $\mathrm{~F}$ & 29 & Trauma & 40 & Granuloma & 4 & I \\
\hline 9 & $M$ & 46 & Trauma & 25 & & 4 & I \\
\hline 10 & $M$ & 50 & Transcanalicular laser DCR & 26 & & 4 & I \\
\hline 11 & $M$ & 49 & Unsuccessful DCR & 17 & Tube dislocation & 4 & 2 \\
\hline 12 & $M$ & 32 & Trauma & 22 & Granuloma & 4 & I \\
\hline 13 & $M$ & 43 & Transcanalicular laser DCR & 25 & & 4 & 2 \\
\hline
\end{tabular}

DCR: Dacryocystorhinostomy.

tion intranasally were revised for 2 times with endoscopy and proximal ends of tubes were resutured. Repositioning of the tube by pulling out from caruncle area with fine forceps was performed only once in two patients. The granulomas were excised and sent to pathology, which revealed chronic inflammatory reaction with foreign body giant cell accumulation.

None of the patients had irritation, pain, and diplopia.

\section{Discussion}

It has been suggested that $<8 \mathrm{~mm}$ of healthy proximal canaliculus or failure of orbicularis oculi muscle and tear pump needs intervention $(2,8,10)$. Epiphora secondary to proximal canalicular obstruction was the main indication for C-DCR operation in this study. The causes of the obstruction of lacrimal system in our study were consistent with previous studies $(2,8,10-13)$. Lim et al. (8) reported that the cause of obstruction was mostly idiopathic and trauma was the most common cause where the etiology was known. In the study of Zilelioğlu and Gündüz and Rosen et al., idiopathic and traumatic obstructions were the most common causes also (12, I3). Unsuccessful lacrimal surgery and trauma were the most common causes in our study.

The Métaireau tube is a flexible silicone tube coated with PVP to have a slick surface to enhance drainage and to prevent occlusion with debris $(14,15)$. It has a round collar with $4 \mathrm{~mm}$ diameter where any suture can be passed easily through its silicone material. The tube length is $40 \mathrm{~mm}$, which can be adjustable by trimming with endoscopy assistance using endonasal scissors during surgery. In this study, we also preferred endoscopy-assisted implantation of Métaireau tube and we adjusted the tube length in the nasal cavity after insertion without touching the septum just anterior and slightly over the middle turbinate. Chang et al. (15) reported that repositioning of the Métaireau tube was simple when performed early. In case of subluxation through the nasal cavity tube can be easily pulled out with fine forceps and if dislocation exists, the tube can be taken out from nasal cavity with endoscope and easily inserted from caruncular area.

Extrusion and dislocation rate, which had been reported as $18-51 \%(2,7,8, I I, 12)$, was found to be $30 \%$ in this study. Putterman-Gladstone tube with additional flange (2, 8 , 16), frosted Jones Pyrex tube with textured outer surface $(7,8,17)$, and porous-polyethylene-coated tube $(8,18)$ were introduced to increase stability in the surgical fistula to overcome dislocation problem. Rose and Welham suggested that surgical tube replacement should perhaps be regarded as a part of expected maintenance, rather than as a complication due to a step-wise increase in Jones tube replacement or repositioning over time and concluded that 100\% of cases would require these procedures if observed over 20 years (10). Malposition was the main factor for our patients to become dissatisfied. In this study, dislocations of the tubes were seen in the first 3 months. This might indicate that instability of the tube position during healing process until the ostium closed around the tube and also increased fibrotic activity in the early post-operative period. 
Obstruction was another complication in our study (22.2\%). To overcome this problem, all patients were advised regular sniffing, cleaning entrance of the tube with cotton swab to remove mucus, and forceful aspiration of water or saline to maintain tube patency as described in previous reports $(2,8,10)$. The most common cause of obstruction was soft tissue hypertrophy or granuloma formation in this study (22.2\%) despite excision of caruncle or redundant conjunctiva in the primary operation. Lim et al. (8) defined an intermediate group with patent, well-positioned, and well-draining tubes but had an intermittent epiphora subjectively and classified them as moderate success due to reversible mucus plugging, movement of the tube resulting in variable drainage, upper respiratory tract infections or allergies resulting in nasal mucosal swelling, and windy weather or air-conditioning precipitating reflex tear hypersecretion. A total of 37 cases were asked about the level of satisfaction in the study of Lim et al. and II of them were dissatisfied due to the cost of a repeat procedure, trouble of maintaining tube, daily cleaning, and eye baths to remove mucus plugs (8). Rosen et al. (13) reported reasons for patient dissatisfaction in $11.6 \%$ of successfully treated patients as the number of follow-up examinations, tube maintenance, tearing in recumbent position, fogging and spraying spectacles, and esthetics. In our study, granuloma formation was seen after I year, which might be due to irritation of conjunctiva and late tissue reaction to tube material.

\section{Conclusion}

Performing C-DCR with Métaireau tube and adjusting the tube position and length with endoscopy assistance is a practical approach in patients with proximal lacrimal system obstruction. Further studies with larger number of participants are necessary to establish the efficacy of implantation of this tube with endoscopy assistance.

\section{Disclosures}

Peer-review: Externally peer-reviewed.

Conflict of Interest: None declared.

\section{References}

I. Goar EL. Congenital absence of the Lacrimal puncta and canaliculi. Trans Am Ophthalmol Soc 1931;29:91-9.

2. Athanasiov PA, Madge S, Kakizaki H, Selva D. A review of by- pass tubes for proximal lacrimal drainage obstruction. Surv Ophthalmol 201 I;56:252-66.

3. Stallard HB. An operation for epiphora. Lancet 1940;2:743-4.

4. Mahmood S, Sadiq A. A short history of lacrimal surgery. J Ophthalmol 2001;5:76-8.

5. Paufique L, Durand L. Surgical treatment of eye watering: Repair of the canaliculus with a venous graft (technic). Ann Ocul (Paris) 1969;202:337-44.

6. Jones LT. Conjunctivodacryocystorhinostomy. Am J Ophthalmol 1965;59:773-83.

7. Steele EA, Dailey RA. Conjunctivodacryocystorhinostomy with the frosted jones pyrex tube. Ophthalmic Plast Reconstr Surg 2009;25:42-3.

8. Lim C, Martin P, Benger R, Kourt G, Ghabrial R. Lacrimal canalicular bypass surgery with the Lester Jones tube. Am J Ophthalmol 2004; 137:101-8.

9. Munk PL, Lin DT, Morris DC. Epiphora: Treatment by means of dacryocystoplasty with balloon dilation of the nasolacrimal drainage apparatus. Radiology 1990; 177:687-90.

10. Rose GE, Welham RA. Jones' lacrimal canalicular bypass tubes: Twenty-five years' experience. Eye (Lond) 1991;5:13-9.

II. Sekhar GC, Dortzbach RK, Gonnering RS, Lemke BN. Problems associated with conjunctivodacryocystorhinostomy. Am J Ophthalmol 1991;1 12:502-6.

12. Zilelioğlu G, Gündüz K. Conjunctivodacryocystorhinostomy with jones tube. A 10-year study. Doc Ophthalmol 1996;92:97105.

13. Rosen N, Ashkenazi I, Rosner M. Patient dissatisfaction after functionally successful conjunctivodacryocystorhinostomy with jones tube. Am J Ophthalmol 1994; I I 7:636-42.

14. Metaireau JP. Treatment of canalicular block. Eye (Lond) 1988;2:220-2.

15. Chang CH, Chen YC, Lee CL, Chu SW. Application of the metaireau tube (M-tube) in conjunctivodacryocystorhinostomy (CDCR). Taiwan J Ophthalmol 2013;3:7I-4.

16. Gladstone GJ, Putterman AM. A modified glass tube for conjunctivodacryocystorhinostomy. Arch Ophthalmol 1985;103:122930.

17. Dailey RA, Tower RN. Frosted jones pyrex tubes. Ophthalmic Plast Reconstr Surg 2005;21:185-7.

18. Wojno T. Experience with a medpor-coated tear drain. Ophthalmic Plast Reconstr Surg 2010;26:327-9. 